Bogdan Stańkowski ORCID: 0000-0003-2803-3085

Akademia Ignatianum w Krakowie

\title{
Biurokratyzacja i ideologizacja w polskiej szkole - wyniki badań własnych
}

\section{Bureaucratization and Ideologization in Polish Schools - the Results of Author's Own Research}

\begin{abstract}
ABSTRAKT
Zagadnienia poruszone $w$ artykule oscyluja wokół środowiska, aktualnych trendów i problemów w edukacji, które kształtuja rzeczywistość polskiej szkoły. Na podstawie dostępnej literatury autor stara się przedstawić problem biurokratyzacji i ideologizacji w polskiej szkole. W artykule sformułowano dwie tezy: 1) edukacja w polskich szkołach na poziomie podstawowym nosi znamiona ideologizacji; 2) nadmierna formalizacja i biurokratyzacja szkoły paraliżuje zdrowq dynamikę edukacji nieodłącznie zwiqzanq ze szkolnq społecznościq uczniów i nauczycieli.

Niniejszy artykuł ma charakter badawczy. W badaniach jakościowych wykorzystano technikę wywiadu pół-ustrukturyzowanego. Do badań wykorzystano kwestionariusz wywiadu pogłębionego przeprowadzonego z 8 nauczycielami klas 4-6 szkoły podstawowej z woj. śląskiego. Celem badań własnych było zgłębianie zjawiska biurokratyzacji i ideologizacji w szkole. Najważniejsze wnioski: a) paradoksalnie, biurokratyzacja w szkole może przynieść pozyływne efekty
\end{abstract}

SLOWA KLUCZOWE biurokratyzacja w szkole, ideologizacja szkoły, edukacja w Polsce, badania empiryczne.

\section{KEYWORDS}

bureaucratization at school, school ideologization, education in Poland, empirical research

SPI Vol. 22, 2019/1

ISSN 2450-5358

e-ISSN 2450-5366

DOI: 10.12775/SPI.2019.1.006

Nadesłano: 28.01.2019 Zaakceptowano: 21.03.2019

Raporty z badań 
w sytuacji, gdy dyrekcja i nauczyciele maja do czynienia z rodzicami roszczeniowymi; b) praktyczne przeakcentowanie zapisów prawnych oraz rozwiqzań biurokratycznych kosztem zdrowego rozsqdku i zasad niepisanego dobrego wychowania może potęgować w nauczycielach postawę wycofania i rezygnacji $z$ wychowania obejmujacego sferę ogólnoludzkq; c) obserwuje się duży napór ideologiczny na szkołę, gdyż nie sq brane pod uwagę realne możliwości szkoły, ale jedynie ślepe posłuszeństwo propagandzie i ideologii lansującej ideę tolerancji jako wartości nadrzędnej; d) zdaniem respondentów treści zawarte w podręcznikach poruszaja realne problemy dzieci (akceptacja niepełnosprawnych, tolerancja wobec ludzi o odmiennej kulturze); e) respondenci nie dostrzegaja jawnych sprzeczności pomiędzy osiqgnięciami poszczególnych nauk, np. psychologii czy pedagogiki, a treściami lansowanymi w podręcznikach; f) ważne miejsce w życiu szkoły z punktu widzenia wielokulturowości zajmuja działania i zwyczaje, które sq dowodem na to, że placówka jest wyczulona na sprawy uczniów innych wyznań i kultur.

\section{ABSTRACT}

The issues raised in the article revolve around the environment, current trends and problems in education that shape the reality of the Polish school. Based on the available literature, the author tries to present the problems of bureaucratization and ideologization in Polish schools. In the article, the author formulated two theses, with the first being as follows: Education in Polish schools at the basic level carries the hallmarks of ideologization. Second thesis: The excessive formalization and bureaucratization of the school paralyzes the healthy dynamics of education inherent in the school community of students and teachers. This article is of a research character with the semi-structured intelligence technique used in the qualitative research. The study involved an in-depth interview questionnaire with eight teachers from elementary school, level 4-6, from the province of Silesia. The purpose of the research was to explore the phenomena of bureaucratization and ideologization at school. The most important conclusions were the following: (a) paradoxically, bureaucratization at school can bring positive effects in the situation when the management and teachers deal with the claims of parents; (b) the practical over-emphasizing of legal provisions and bureaucratic solutions at the expense of common sense and the principles of unwritten good manners may intensify the attitude of withdrawal and resignation from upbringing in teachers; (c) there is a strong ideological pressure on schools because the real possibilities 
of the school are not taken into account, but only blind obedience to propaganda and an ideology that promotes the idea of tolerance as a superior value; (d) according to the respondents, the content contained in the textbooks addresses the real problems of children (acceptance of the disabled, tolerance towards people with a different culture); (e) respondents do not see any open contradictions between the achievements of particular sciences, e.g. psychology or pedagogy, and the content promoted in textbooks; ( $f$ ) an important place in the school's life from the point of view of multiculturalism is occupied by activities and habits that are proof that the institution is sensitive to the affairs of students of other faiths and cultures.

\section{Wstęp}

Społeczeństwo polskie i z całą pewnością również polska szkoła od 1989 roku przeżywa kryzys. Ciągłe reformy szkoły, często krytykowane przez ekspertów, zatrzymywanie się na płaszczyźnie dydaktyki, kosztem wychowania, wszechobecna konkurencyjność i dążenie do zwiększenia efektywności kształcenia, kryzys aksjologiczny społeczeństwa - wszystko to potęguje niewydolność polskiej szkoły i paraliż w aspekcie wychowania. Niektóre trendy w społeczeństwie europejskim, ale można też powiedzieć, że i w polskim, fundują nam swego rodzaju terroryzm ideologiczny ${ }^{1}$. W kontekście wychowania i szkoły dostrzega się pewną rozbieżność pomiędzy wychowaniem a wizją osoby ${ }^{2}$. Dostrzegalna jest też pewna niechęć środowisk szczególnie liberalnych do zgłębiania zagadnienia wychowania na płaszczyźnie filozoficznej i egzystencjalnej/religijnej³. Od kilku już lat słyszymy postulaty o przestrzeganiu tzw. „neutralności światopoglądowej” w środowisku wychowawczym. Badacze zauważają, że owa „neutralność światopoglądowa” jest coraz częściej lansowana

1 G. Mucci, I cattolici nelle temperie del relativismo, Milano 2005, s. 62.

2 O łączeniu tych dwóch wymiarów mówi między innymi V. Possenti, L’uomo postmoderno, Milano 2009, s. 108.

3 Nauki empiryczne (psychologia, socjologia itp.) nie są w stanie dostarczyć podstaw, które wskazywałyby na cele wychowania. Ów cel znajdujemy podejmując rozważania dotyczące bytu ludzkiego na płaszczyźnie filozoficznej i religijnej. Pierwsza dostarcza informacji na temat natury człowieka, druga wskazuje na sytuację egzystencjalną człowieka i jego przeznaczenie. Por. V. Possenti, L'uomo postmoderno, dz. cyt., s. 111. 
w kontekście szkoły, co oznacza również jej indoktrynację. Uszczuplanie autorów-klasyków polskiej literatury na rzecz tekstów pisanych przez osoby o odmiennych orientacjach seksualnych, dobór listy lektur nie tyle w kluczu merytorycznej oceny przydatności tekstu ile w kluczu konieczności tolerancji osób homoseksualnych budzi wiele zastrzeżeń co do kryteriów doboru tekstów oraz co do pojawiania się nowych celów wychowania i kształcenia. Obecnie wielu pedagogów w swoich badaniach pochyla się nad licznymi patologiami nękającymi system edukacji w Polsce (szkodliwy wpływ ideologii, nadmierna biurokratyzacja oświaty itp. $)^{4}$.

Niniejszy artykuł ma charakter badawczy. W pierwszej części autor przybliża środowisko, aktualne trendy i bolączki w oświacie, które kształtują rzeczywistość szkolną. Wspomniane rozważania pozwoliły autorowi na sformułowanie dwóch tez, które dzięki badaniom własnym będą mogły być poddane weryfikacji. Pierwsza z nich brzmi następująco: Edukacja w polskiej szkole na poziomie podstawowym nosi znamiona ideologizacji. Druga teza: Nadmierna formalizacja i biurokratyzacja szkoły paraliżuje zdrowe dynamizmy wychowawcze, tkwiące w społeczności szkolnej uczniów i wychowawców.

W badaniach jakościowych wykorzystano technikę wywiadu półustrukturyzowanego. W wywiadach wzięli udział nauczyciele klas 4-6 szkoły podstawowej z woj. śląskiego.

\section{Fenomen biurokratyzacii i ideologizacji w przestrzeni szkolnej}

Trudno zaprzeczyć temu, że edukacja od wieków jest ważnym elementem kontroli społecznej. Ideolodzy, rządzący, biurokraci mniej lub bardziej korzystali z tego potencjału, upatrując często w edukacji szans na podporządkowanie sobie pewnych grup społecznych czy jednostek. Ten fenomen staje się przyczynkiem do refleksji i namysłu nad rolą urzędników i ideologów w kształtowaniu szkolnej rzeczywistości w Polsce. Autorzy ubolewają nad faktem, że systemy edukacyjne współczesnych państw zostały zsekularyzowane i poddawane są

4 Warto w tymi miejscu wspomnieć o XIII Międzynarodowej Konferencji Naukowej „EDUKACJA XXI WIEKU. Patologie edukacji XXI wieku. Ideologia, polityka, biurokracja”, zorganizowanej w październiku 2015 r. w Szczyrku. 
coraz dalej idącym eksperymentom w obszarze kształcenia i wychowania. W szkołach widoczny jest wpływ różnego rodzaju ideologii, gdyż odchodzi się od zasad realistycznego myślenia na rzecz idealizmu (istnieje tylko to, co jest wytworzone w naszym umyśle) ${ }^{5}$.

Biurokratyzacja $\mathrm{w}$ potocznym pojęciu oznacza nadmierne sformalizowanie oraz scentralizowanie systemu ( $\mathrm{z}$ fr. bureau - urząd i gr. kratos - władza). W kontekście szkoły może oznaczać przesadne obejmowanie procedurami i przepisami każdego wymiaru rzeczywistości szkolnej. Autorzy zauważają, że współczesny polski system oświatowy jest hiperadministracyjny, zbiurokratyzowany, ograniczający wolność pedagogiczną różnych organów szkolnych ${ }^{6}$. Bezduszne przepisy, skomplikowane procedury, prowadzą do podporządkowania życia szkoły systemowi biurokratycznemu, stworzonemu przez urzędników na szczeblu ministerstwa ${ }^{7}$. J. Pająk zauważa, że dominująca rola $\mathrm{w}$ kwestiach edukacji przypada szczeblowi centralnemu, odpowiedzialnemu za tworzenie prawa $\mathrm{w}$ dziedzinie oświaty ${ }^{8}$. Biurokratyzacja sprzyja „produkowaniu” przepisów i procedur, ale zarazem niejako chroni urzędnika przed odpowiedzialnością za podejmowane decyzje. Na temat biurokratyzacji w szkole jest dość głośno w mediach. Z uwagi na temat dość „ryzykowny” wielu nauczycieli porusza wspomnianą kwestię w sposób anonimowy ${ }^{9}$. Nie brakuje jednak

5 A. Górecki, Edukacja (deprawacja) seksualna przejawem ideologizacji szkoty, w: http://christianitas.org/news/edukacja-deprawacja-seksualna-przejawem-ideologizacji-szkoly/ [dostęp: 08.11.2015].

6 Por. B. Śliwerski, Pozory sprawstwa reform oświatowych w III RP, w: Sprawcy i/lub ofiary dziatań pozornych we edukacji szkolnej, red. M. Dudzikowa, K. Knasiecka-Falbierska, Kraków 2013, s. 105.

7 Zob. artykuł Z. Rykiela, który co prawda mówi o ideologizacji i biurokratyzacji szkolnictwa wyższego, ale moim zdaniem problemy szkolnictwa to mechanizm naczyń połączonych, dlatego też pewne spostrzeżenia i wnioski autora odnoszące się do szkolnictwa wyższego są ważne również dla szkolnictwa podstawowego. Zob. Z. Rykiel, Szaleństwo czy metoda? Modernizacja przez biurokratyzacje i prekaryzacje, w: http://socialspacejournal.eu/8\%20numer/Zbigniew\%20Rykiel\%20-\%20Szale\%C5\%84stwo\%20czy\%20metoda. pdf [dostęp: 04.11.2015].

8 J. Pająk, Kultura organizacyjna w oświacie. Teoria - praktyka - stymulacja, Katowice 1996, s. 30-32.

9 Autor anonimowy, Biurokracja zabija szkote, w: http://wyborcza.pl/magazyn /1,128598,12659823,Biurokracja_zabija_szkole.html?disableRedirects=true [dostęp: 04.11.2015]. 
merytorycznej krytyki tego fenomenu zawartej na łamach poczytnych gazet ${ }^{10}$. Media donoszą również o pewnych próbach uzdrowienia wspomnianej sytuacji ${ }^{11}$. Niektórzy nauczyciele proponują, aby dać większą autonomię szkole i zdecentralizować system zarządzania oświatą. Postulują również zmiany w kwestii zarządzania finansami i organizacją szkoły. Zalecają konieczność spisania, które dokumenty szkolne są rzeczywiście wskazane, i uregulowania ich wykazu odpowiednim obowiązującym rozporządzeniem tak, aby odrzucić „radosną twórczość urzędników"12. Ideą polityków prawicowych jest, aby nie przyczyniać się do dalszej biurokratyzacji szkół, i aby nauczyciel szkoły podstawowej spędzał z uczniem jak najwięcej czasu, poznając jego talenty, problemy, potrzeby, dając rodzicom wskazówki do wspólnego działania ${ }^{13}$. Badacze zauważają, że centralizm oświatowy, nadaktywność reorganizacyjna oraz hiperlegalizm skutkują biurokratyzacją działań szkoły, brakiem jej rozwoju, widocznego celu, który szkoła ma realizować ${ }^{14}$. B. Śliwerski na swym blogu często wyczula czytelników na problem biurokratyzacji i centralizacji, które niszczą polską szkołę. Cytowani przez niego autorzy podkreślają przede wszystkim fenomen przenikania władzy urzędniczej do różnych obszarów edukacji szkolnej, niszcząc tym samym wartość podmiotowości nauczycieli, uczniów i dyrektorów szkół ${ }^{15}$.

10 A. Grabek, Szkota przesiaknięta biurokracja, w: http://praca.gazetaprawna.pl/artykuly/550588,szkola_przesiaknieta_biurokracja.html [dostęp: 4.11.2015].

11 Z. Magdziak, Mniej biurokracji w szkole, w: http://www4.rp.pl/artykul/ 945624-Mniej-biurokracji-w-szkole.html [dostęp: 04.11.2015]. Zob. także J.P. Sawiński, Jak ujarzmić (eliminować) szkolna biurokrację? w: http://www. edunews.pl/badania-i-debaty/opinie/1745-jak-ujarzmic-eliminowac-szkolna-biurokracje [dostęp: 04.11.2015].

12 Absurdy biurokratyczne w oświacie, w: http://www.warszawskieforumoswiatowe.pl/index.php?site=hsite\&id=17 [dostęp: 04.11.2015].

13 Wypowiedź B. Nowak w wywiadzie dla P. Ogórek, PIS: zdemolowano caty system nauczania, w: http://wiadomosci.onet.pl/krakow/pis-zdemolowano-caly-system-nauczania/p4dhnf [dostęp: 04.11.2015].

14 Zob. więcej w: M. Dąbrowska-Bąk, K. Pawełek, Opresja w szkole, Warszawa 2014.

15 B. Śliwerski, Na horyzoncie wyborów do Sejmu - MEN-ska polityka btędów: arogancji, ignorancji, centralizmu i biurokratyzacji, w: http://sliwerski-pedagog.blogspot.com/2015/07/na-horyzoncie-wyborow-do-sejmu-men-ska. html [dostęp: 12.03.2019]. 
Innym zjawiskiem, które można dostrzec na polskiej scenie, jest aspekt ideologizacji przestrzeni społecznej. Otwarcie mówi się o ideologizacji polskiej nauki ${ }^{16}$. Słusznie zauważa P. Jaroszyński, że nawet jeśli nie można wprost zideologizować nauk matematyczno-fizykalnych, to jednak można poprzez ingerencję w ich przesłanki lub metody manipulować nimi, dokonując ekstrapolacji niektórych twierdzeń, czy wypełniając nimi liczne programy edukacyjne, kosztem nauk humanistycznych. Istnieje też niebezpieczeństwo, że nauki przyrodnicze zostaną podporządkowane czysto biologicznej wizji człowieka (patrz materializm marksistowski) ${ }^{17}$. Autorzy zauważają, że ideologie konstruowane są zazwyczaj w opozycji do religii, a w szczególności do chrześcijaństwa. W zideologizowanym społeczeństwie wszystko ma być poddane kontroli administracji i władzy politycznej. Mowa tutaj o rodzinie, szkole, religii, kulturze, mediach oraz o edukacji szeroko pojętej ${ }^{18}$. Aktualnie w kontekście szkoły dają się zauważyć różne koncepcje, które kierują się określoną filozofią, czy wręcz ideologią (np. koncepcja marksistowska szkoły, laicka, antypedagogiczna, radykalno-emancypacyjna, technologiczna, czy też koncepcja „szkoły waldorfskiej”) ${ }^{19}$. Jak zauważa M. Nowak, „większość tych koncepcji, opierając się na przyjętej ideologii, rozmijając się z rzeczywistością, pomija ucznia i wychowanka oraz nauczyciela, lub zawęża ich rolę np. do funkcjonariusza realizującego cele ideologii, budując iluzoryczną rzeczywistość, jaką wydaje się obiecywać ideologia. Nie liczą się uwarunkowania rozwojowe czy środowiskowe, lecz te są poddane kryteriom przyjmowanej ideologii”20. Współczesna Europa jest bardzo zaangażowana w kształtowanie nowego pokolenia, co oznacza, że trwa namysł nad tym, jaką osobę wychować, jakie wartości proponować

16 Zob. M. Kowalski, Nobilitowanie ideologii spotecznych przy pomocy nauki (ideologizowanie nauki) - analizy i refleksje, „Rocznik Lubuski” 2012, t. 38, cz. 2, s. 191-199.

17 Zob. P. Jaroszyński, Cztowiek i nauka, Lublin 2008, s. 242-283.

18 J.M. Jackowski, Szkota nadal w okowach ideologii, w: http://www.radiomaryja.pl/bez-kategorii/szkola-nadal-w-okowach-ideologii/ [dostęp: 04.11.2015].

19 Zob. M. Nowak, Koncepcja szkoty i jej zadania we wspótczesnej myśli pedagogicznej, w: Szkoła - Nauczyciel - Uczeń, red. T. Kukołowicz, Stalowa Wola 1992, s. 5-22.

20 Zob. tamże, s. 18-21. 
młodym ludziom ${ }^{21}$. Jednocześnie podkreśla się, że u podstaw wychowania i kształcenia leży wcześniej przyjęta koncepcja człowieka i jego działania ${ }^{22}$. Co prawda Konstytucja Rzeczypospolitej Polskiej gwarantuje obywatelom jako „demokratyczne państwo prawne” bezstronność w sprawach religijnych i światopoglądowych, ale w rzeczywistości dostrzegamy ciagłe ścieranie się różnych opcji, szczególnie tej chrześcijańskiej i liberalnej, postmodernistycznej. Jak zauważa B. Śliwerski, postmodernizm zrywa z poszukiwaniem optymalnego wychowania. W postmodernistycznej pedagogice nie obowiązuje już autorytet, nie ma apelowania do posłuszeństwa, przestrzegania norm czy też postępowania według wzorów. Kategorią, które dominuje w społeczeństwie postmodernistycznym, jest dobrowolność. W tej perspektywie takie pojęcia, jak „prawa rodziców”, „dobro dziecka”, „socjalizacja”, „potrzeby”, budzą zdaniem tego autora uzasadnione obawy i wątpliwości ${ }^{23}$.

Oświata jest siłą, która wpływa na przebudowę rzeczywistości, dlatego też sprawujący władzę ze wszech miar chcą mieć na nią wpływ i w nią ingerują $2^{24}$. Do ideologii, związanej często z wpływowym ugrupowaniem politycznym, dopasowuje się różne modele wychowania, strategie kształcenia, narzędzia oddziaływania. Proces szczególnej biurokratyzacji i ideologizacji w polskiej szkole można było dostrzec po II wojnie światowej ${ }^{25}$. Także w ostatnich latach autorzy alarmują o szerzącej się ideologizacji polskiej szkoły. ${ }^{26}$. Ważnym elementem właśnie wspomnianego oddziaływania na dzieci i młodzież jest personalistyczne, Wybór tekstórw, red. F. Adamski, Kraków 2005, s. 133-153. Zob. zbieżność pomiędzy brakiem koncepcji wychowania a trudnościami wychowania w szkole: A. Kącki, Niemoc wychowania w szkole jako następstwo braku koncepcji wychowania, czyli o autarkii i acedii postmodernistycznej pedagogiki, w: Wychowanie w szkole: od bezradności ku możliwościom, red. R. Chałupniak, T. Michalewski, E. Smak, Opole 2014, s. 81-86. Zob. B. Śliwerski, Nauki o wychowaniu wobec wyzwań postmodernizmu, "Chowanna” 2003, t. 1 (20), s. 11.

24 
umiejętny dobór lektur szkolnych. Jak zauważa Z.A. Kłakówna, istnieją liczne bolączki, które trapią ten wymiar wychowania poprzez literaturę (lekturę). Autorka podkreśla przede wszystkim fakt nieliczenia się ministerialnych urzędników w momencie doboru zestawu lektur z aktualną wiedzą psychologiczną, jaką posiadają uczniowie. Arbitralne przydzielanie książek sprzyja także ideologizacji nauczania, instrumentalnemu traktowaniu lektury ${ }^{27}$. Najbardziej chyba widocznym polem walki ideologicznej w szkole staje się problem wychowania seksualnego dzieci i młodzieży. Ożywiona dyskusja na powyższe tematy często pojawia się na portalach internetowych ${ }^{28}$. Zdaniem autorów, polska szkoła, szczególnie podstawowa, posiada dobrą podstawę programową, jeśli chodzi o przedmiot Wychowanie do życia w rodzinie. Jednakże podstawa programowa jest dokumentem dość ogólnym, natomiast nagłaśniane sytuacje zagrożeniowe, szczególnie chodzi o propagowanie ideologii gender, moga pojawiać się w programach i materiałach pomocniczych, które są oferowane przez instytucje pozarządowe, propagujące libertynizm obyczajowy (przykładem może być program Fundacji Nowoczesnej Edukacji SPUNK z Łodzi, powiązanej z fundacją „Jaskółka”, zajmującej się prowadzeniem edukacji seksualnej w szkołach, czy też program „Równościowe Przedszkole”). Badacze przestrzegają przed pójściem za takim humanizmem, który uważany jest za „uczciwy” i „neutralny” wobec wszelkich światopoglądów bądź ideologii. W rzeczywistości każdy autor (Kafka, Gombrowicz, Goethe, Kierkegaard i inni) prezentuje określoną wizję człowieka, czy to materialistyczną, czy ateistyczną, czy też nihilistyczną, a ta wizja może stać się narzędziem propagandy w ręku nauczyciela, kiedy korzysta $z$ treści prezentowanych przez autorów nie stroniących od skrajnych ideologii ${ }^{29}$. Aktualnie w naszej przestrzeni społecznej

Zob. Z.A. Kłakówna, Opinia na temat listy lektur z jezzyka polskiego w szkole podstawowej z widokiem na gimnazjum i liceum. Klasy I-III (I etap edukacyjny) oraz klasy IV-VI (drugi etap edukacyjny), „Horyzonty Polonistyki” 2008, nr 1, s. 8-11.

28 Zagłada tożsamości w ideologii gender, w: https://prawdaxlxpl.wordpress. com/2013/04/21/ [dostęp: 09.11.2015].Zob. też: M. Nowak, Edukacja daleka od chrześcijaństwa, w: http://www.fronda.pl/a/edukacja-daleka-od-chrzescijanstwa,31291.html [dostęp: 10.11.2015].

29 Zob. A. Posacki, Szkota tatwych pocieszeń czy dogmatyzacja fatszywych dylematów?, w: http://www.radiomaryja.pl/bez-kategorii/szkola-latwych-pocieszen-czy-dogmatyzacja-falszywych-dylematow/ [dostęp: 10.11.2015]. 
dostrzegalny jest wzmożony dyskurs na temat genderyzmu ${ }^{30}$. Rozróżnienia o fundamentalnym znaczeniu dla rozwoju badań z zakresu kobiecości i męskości dokonała A. Oakley, która wyodrębniła „płeć biologiczną” (sex) oraz „płeć kulturową” (gender). Pierwsza odnosi się do różnic anatomicznych i fizjologicznych między płciami i określa ją jako niezmienną. Druga, czyli płeć kulturowa (gender), odnosi się do różnic psychologicznych, społecznych i kulturowych, które zmieniają się w zależności od kontekstu społecznego ${ }^{31}$. W ostatnich kilkunastu latach w Europie szeroko propagowana jest wizja płci kulturowej, która już w latach siedemdziesiątych ubiegłego wieku była lansowana przez egzystencjalistów w osobie Simone de Beauvoir ${ }^{32}$. Oznaki ideologii gender coraz częściej są zauważalne w polskiej przestrzeni szkolnej ${ }^{33}$. W dyskursie chrześcijańsko-prawicowym przeważa opinia, że ideologia gender trudna jest do pogodzenia $\mathrm{z}$ chrześcijańską koncepcją osoby, tożsamością kobiety i mężczyzny oraz z pojmowaniem ludzkiej płciowości ${ }^{34}$. Przedstawiciele ideologii feministycznych koncentrują swe wysiłki nie tylko w kwestii równości płci, ale również szczególny nacisk kładą na edukację seksualną $a^{35}$. Przeważają głosy krytyczne

Zob. tematykę Międzynarodowej Konferencji zorganizowanej na UPJP II w Krakowie w marcu 2015: Gender-spojrzenie krytyczne. Ważnym przedstawicielem zagranicznych autorów, którzy krytycznie podchodzą do ideologii gender jest Gabriele Kuby. Zob.: G. Kuby, Rewolucja genderowa. Nowa ideologia seksualności, Kraków 2007.

31 A. Oakley, Sex, Gender and Society, London 1972, s. 130-134.Zob.A. Giddens, Socjologia, przel. O. Siara i inni, Warszawa 2012, s. 601-604.

32 S. de Beauvoir, Druga pté́, przeł. G. Mycielska, Kraków 1972, s. 77-80.

33 Takim symptomem może być np. udział przedstawicieli MEN w konferencji w 2013 r. poświęconej prezentacji „Standardów Edukacji Seksualnej w Europie". Wśród wytycznych można zauważyć chęć wpajania dzieciom takich zachowań, jak masturbacja, techniki seksualne, petting, zabawa ciałem. Jest też mowa o rozumieniu przez dziecko pojęcia „akceptowany seks” czy w odniesieniu do 12-latka umiejętność „komunikowania się w celu uprawiania przyjemnego seksu". Zob. A. Górecki, Edukacja (deprawacja), seksualna przejawem ideologizacji szkoty, dz. cyt. Podobne problemy szkoły z ideologią gender można zauważyć również w innych krajach. Zob. G. Amato, Gender (d) Istruzione. Le nuove forme d'indottrinamento nelle scuole italiane, Verona 2015. Zob. A. Zellma, Wspótczesny katecheta - między chrześcijańskim powotaniem i misja a idea gender, w: Idea gender jako wyzwanie dla teologii, red. A. Jucewicz, M. Machinek, Olsztyn 2009, s. 173-185.

35 Zob. rozpatrywany w Sejmie odrzucony projekt ustawy dotyczący tej problematyki. Druk sejmowy 1298 (VII kadencja Sejmu RP). Projekt odrzucono 
względem tejże wizji człowieka, podkreślające przede wszystkim, że jest to ideologia, która odbiega zarówno od tradycji, jak też od ustaleń naukowych, szczególnie w zakresie nauk przyrodniczych ${ }^{36}$. Również środowiska katolickie i prawicowe określają ideologię gender jako bunt wyemancypowanego człowieka wobec świata tradycyjnego. Podkreśla się destrukcyjny charakter wspomnianej ideologii wobec człowieka, w stosunku do relacji międzyludzkich, a tym samym do całego życia społecznego ${ }^{37}$. Zgodnie $\mathrm{z}$ tą perspektywą, rola, jaką w społeczeństwie mają do spełnienia dzieci, byłaby wytworem kulturowym, nie zaś obiektywnym faktem. Zdaniem D. Zalewskiego, ma to swoje podłoże w marksistowskiej frazeologii, gdzie „walka płci” czy „walka pokoleń” staje się przedłużeniem leninowskiej „walki klas”38. Autorzy przestrzegają przed sytuacją, w której nauczyciel zamiast stawać się mistrzem wszczepiającym cnoty obywatelskie i rzetelnie przekazującym wiedzę, sprowadzany byłby do roli bezrefleksyjnego funkcjonariusza ideologii ${ }^{39}$.

Częścią integralną procesu ideologizacji szkoły jest promowanie tzw. neutralności światopoglądowej szkoły. Dla wielu autorów jest rzeczą oczywistą, że szkoła winna być neutralna politycznie i ideologicznie, a stawać się przestrzenią otwartą, wyczuloną na promowanie

na posiedzeniu nr 66 dnia 24 kwietnia 2014 r. Wkradanie się ideologii gender do szkoły włoskiej sygnalizuje prawniczka E. Frezza w swej publikacji Mala Scuola - "Gender”, affettività, emozioni: il sistema „educativo” per abolire la ragione e manipolare i nostri figli (tłum. własne: Zła szkoła - "Gender”, uczuciowość, emocje: system „edukacyjny” dla zniesienia rozumu i manipulowania naszymi dziećmi), Roma 2017.

36 Zob. A. Wielomski, Genderyzm czyli szalenstwo importowane z zachodniego śmietnika ideologii, w: http://nczas.com/publicystyka/genderyzm-czyli-szalenstwo-importowane-z-zachodniego-smietnika-ideologii/ [dostęp: 10.11.2015].

37 Abp Hoser: Gender to wielkie ktamstwo, w: http://wiadomosci.wp.pl/ kat,137914,title,Abp-Hoser-gender-to-wielkie-klamstwo,wid,16289558, wiadomosc.html?ticaid=115ead [dostęp: 10.11.2015].

38 Por. D. Zalewski, Antypedagogika i inne herezje, w: http://www.psychologia.net.p1/e-booki/Dariusz_Zalewski-Antypedagogika_i_inne_herezje.pdf [dostęp: 12.11.2015].

39 Zob. K. Warecki, Nauczyciel jako funkcjonariusz ideologii, w: http://gosc. $\mathrm{pl} /$ doc/2197730.Nauczyciel-jako-funkcjonariusz-ideologii/2 [dostęp: 10.11.2015]. 
wartości i ideałów ${ }^{40}$. Lansowana idea, że wychowanie, a tym samym również kształcenie oraz nauczanie posiadają filozoficzny charakter, związany z przyjętą w punkcie wyjścia szkołą filozoficzną, jej wizją człowieka, działania, coraz częściej jest podważana i marginalizowana. To rodzi chęć tworzenia szkoły i budowania wychowania na tzw. neutralności światopoglądowej ${ }^{41}$. Powyższa idea spotyka się jednak z opinią o jej utopijnym charakterze, gdyż w praktyce za każdą metodą wychowania stoi określona wizja człowieka, którego chce się ukształtować i wychować ${ }^{42}$. M. Dobrowolski podkreśla, że w Konstytucji RP nie istnieje sformułowanie: „neutralność światopoglądowa”. Zauważa natomiast, że zawiera ona sformułowanie mówiące o bezstronności religijnej i światopoglądowej władzy publicznej i państwowej (Konstytucja RP, art. 25, ust. 2). W związku z powyższym wspomniany autor podkreśla, że organy administracji państwowej mają wykazać się swoją bezstronnością wobec światopoglądu nauczycieli, rodziców i dzieci, a tym samym nie mogą narzucać im swojego światopoglądu ${ }^{43}$. Również hierarchowie Kościoła katolickiego w osobie abp. S. Gądeckiego uznają, iż owa neutralność światopoglądowa pozornie brzmi przekonująco, natomiast w rzeczywistości niemożliwa jest do spełnienia ${ }^{44}$. Pogląd B. Milerskiego w kwestii neutralności światopoglądowej szkoły jest o wiele bardziej krytyczny, jednakże autor ten nie wyklucza form indywidualnego poświadczania przekonań aksjologicznych przez nauczycieli i uczniów,

J. Galant, Czy szkoła może być neutralna światopogladowo?, „Nowa Szkoła” 1997, nr 5, s. 14.

41 Por. opinię byłej minister edukacji J. Kluzik-Rostkowskiej, która jest zdania, że polska szkoła potrzebuje neutralności światopoglądowej. Zob. Joanna-Kluzik-Rostkowska: szkota publiczna powinna być neutralna światopogladowo, w: http://wiadomosci.wp.pl/kat,1342,title,Joanna-Kluzik-Rostkowska-szkola-publiczna-powinna-byc-neutralna-swiatopogladowo,wid,16784101 , wiadomosc.html?ticaid=115ee0 [dostęp: 12.11.2015].

42 B. Stańkowski, Meanders of upbringing and worldview neutrality, w: Rolul Europei într-o societate polarizată. Conferința internațională de drept, studii europene şi relaţii internaţionale, Bucureşti, 9-10 mai 2014, s. 830-845.

43 Por. M. Pabis, Neutralna, czyli ateistyczna, w: http://www.naszdziennik.pl/ polska-kraj/88411,neutralna-czyli-ateistyczna.html [dostęp: 12.11.2015].

${ }_{44}$ Zob. M. Wilgocki, Arcybiskup Gądecki do minister edukacji: Neutralność światopogladowa? Niemożliwa do spetnienia, w: http://wyborcza. p1/1,76842,16409224,Arcybiskup_Gadecki_do_minister_edukacji_Neutralnosc.html?disableRedirects=true [dostęp: 12.11.2015]. 
gdyż jak to określa, owo ujawnianie przekonań przynależy do istoty relacji wychowawczej ${ }^{45}$. Kończąc, należy podkreślić, że polski model neutralności określany jest jako „neutralność otwarta”, co oznacza, że państwo traktuje jednakowo wszystkich ludzi, bez względu na ich przekonania czy wyznanie. Art. 23 , ust. 2 Konstytucji RP wyraża więc neutralność tego typu, gdzie władza publiczna nie może być neutralna wobec ludzkiej godności i praw człowieka ${ }^{46}$.

\section{Aspekty metodologiczne badań własnych}

Celem badań własnych było zgłębianie zjawiska biurokratyzacji i ideologizacji w szkole. Do badań własnych użyto narzędzia w postaci kwestionariusza wywiadu pogłębionego, przeprowadzonego z 8 nauczycielami uczącymi w szkole podstawowej, w klasach 4-6, w województwie śląskim. ${ }^{47}$

Do badań jakościowych wykorzystano technikę wywiadu pogłębionego. Badacz mógł rozmawiać z respondentem w „cztery oczy”. Wspomniana technika pozwoliła na uzyskanie szczegółowych opinii i informacji na temat funkcjonowania szkoły, oraz relacji interpersonalnych, jakie dają się zauważyć we wspomnianej placówce. Zaletą tej techniki jest również możliwość wyjaśnienia mechanizmów i natury badanych fenomenów, które trudno byłoby uzyskać innymi technikami. Aspekt braku negatywnego wpływu na respondenta ze strony grupy, tematyka kontrowersyjna podejmowana $\mathrm{w}$ badaniach oraz konieczność zachowania intymności w uzyskiwaniu informacji - to czynniki, które stały się kryteriami doboru techniki relacjonowanych tu badań. W doborze nauczycieli do wywiadów wzięto pod uwagę ich staż pracy oraz rodzaje nauczanych przez nich przedmiotów. Średni czas wywiadu wynosił minimum 1 godz. W niektórych przypadkach wywiad przybierał formę bardziej rozszerzoną

45 Zob. B. Milerski, Edukacja religijna w szkole neutralnej światopogladowo, w: http://ekumenia.pl/wp-content/uploads/2014/03/Edukacja-religijna-w-szkole-neutralnej-swiatopogladowo-B.Milerski.pdf [dostęp: 12.11.2015].

46 J. Krukowski, Kościót i państwo, podstawy relacji prawnych, Lublin 2000, s. 282.

${ }_{47} \mathrm{Z}$ uwagi na drażliwy temat badań, badacz był proszony o zachowanie anonimowości respondentów, jak również o nieujawnianie miejsca przeprowadzonych badań. 
i trwał nie więcej niż 1,5 godz. W badaniach zastosowano wywiad półustrukturyzowany. Zaletą takiego podejścia był fakt, że zastosowano listę pytań ustalonych przez badacza, ale generowano również nowe pytania $\mathrm{w}$ trakcie rozmowy, zależnie do przebiegu wywiadu. Tak więc zarysowany scenariusz wywiadu ulegał zmianie, co pozwalało respondentowi na większą swobodę wypowiedzi wokół wątków, które wymagały dodatkowych pytań, rozszerzających omawiane kwestie. Atmosfera wytworzona przez badacza sprzyjała klimatowi poufności i otwierania się nauczycieli na drażliwe a zarazem palące problemy szkoły, co przekładało się na szczere ujawnianie indywidualnych opinii, dotyczących meandrów rzeczywistości szkolnej w aspekcie biurokratyzacji i ideologizacji.

\section{Omówienie wyników badań własnych.}

\section{Relacje interpersonalne w przestrzeni szkolnej}

Zdaniem nauczycieli, rodzice zbyt często ingerują w relacje dziecko-dziecko/rówieśnik. Respondenci uważają, że konflikty między dziećmi rodzą się coraz częściej z braku tzw. „życia podwórkowego” samych uczniów. Brak w pozaszkolnym życiu dziecka bezpośrednich relacji z kolegami skutkuje tym, że dziecko nie potrafi stworzyć na terenie szkoły silnych relacji z rówieśnikami. To sprzyja rodzeniu się konfliktów między dziećmi. „Rodzice zapominają, że niewielkie konflikty pomiędzy dziećmi rozwiązywane są przez same dzieci, które przecież jakoś „dogadują się” po kilku chwilach” (kobieta, lat 52). Ignorowanie tej rzeczywistości prowadzi do kolejnych, nowych procedur biurokratycznych rozwiązań ze strony dyrekcji, która ciągle musi nanosić korektę, uwzględniającą nowe sytuacje w relacjach dziecko-rodzic-szkoła. Ciekawostką jest to, że problemy dyscyplinarne rodzą się głównie wśród tzw. jedynaków (nota bene w jednej z klas na 24 osoby aż 10 uczniów to jedynacy/jedynaczki). Zdaniem nauczycieli, dziecko-jedynak ma większe trudności na płaszczyźnie współpracy z innymi dziećmi, częściej obraża się i nie potrafi rozwiązywać pokojowo zaistniałych konfliktów. Jedna z respondentek zauważa, że niektórzy rodzice są pretensjonalni, ciągle przeświadczeni, że ich dzieci są krzywdzone, gdy otrzymają ocenę negatywną. Inne osoby badane podkreślają, iż o wiele szkodliwszą praktyką jest to, że rodzice bardziej ufają swoim dzieciom niż wychowawcy. 
W ten sposób nauczyciel traci autorytet w oczach dziecka z powodu zachowania rodzica.

Respondentów niepokoi fakt, że wizytator „wierzy rodzicom na słowo, natomiast nauczyciele, dyrekcja, muszą wszystko mieć na piśmie" (kobieta, lat 47). W sytuacji zaistniałego problemu z uczniem wizytator wierzy „bezgranicznie” rodzicom i uczniom, słucha ich wypowiedzi, nawet jeśli są ogólnikowe, i nie wymaga obecności świadków zajścia. Natomiast przy tej samej sprawie, gdy nauczyciel przedstawia pewną „wersję wydarzeń”, ,jego słowa nie mają „mocy”, jest mało wiarygodny w oczach wizytatora, wszystko musi udokumentować, potwierdzić dowodami” (kobieta, lat 51).

\section{Biurokratyzacja w przestrzeni szkolnej}

Na podstawie wypowiedzi respondentów łatwo można zauważyć, że problem biurokratyzacji w szkole jest wszechogarniający. Praktycznie każdy aspekt życia szkolnego podporządkowany jest regułom biurokratyzacji. Oto niektóre tylko jej przejawy: a) rodzice zobowiązani są do podpisywania zgody na każdą najdrobniejszą inicjatywę czy wydarzenie; b) do każdego wyjazdu, wycieczki winien być tworzony nowy regulamin na każdym poziomie nauki, czyli inny dla klas 1-3, inny dla klas 4-6; c) tworzy się procedury dyżurów nauczycieli w czasie przerw. Zdaniem nauczycieli, wspomniane procedury powstały z uwagi na absurdalne rozporządzenia dyrekcji w kwestii obecności nauczycieli wśród uczniów na przerwach (np. ten sam nauczyciel miał obowiązek zakończyć lekcję o ustalonej godzinie, wypuścić dzieci z klasy, zamknąć klasę, odnieść pomoce dydaktyczne i o tej samej godzinie punktualnie podjąć dyżur na ostatnim piętrze);

d) zakaz spożywania posiłków w szkole przez nauczycieli.

Problem biurokratyzacji odczuwalny jest również w aspekcie ewaluacji szkoły. Respondenci są zdania, że ewaluacja szkoły niesie ze sobą dodatkową biurokratyzację, wymaga dużego nakładu pracy od nauczycieli, co w efekcie nie przekłada się na uzyskanie rzeczywistego obrazu szkoły pod kątem jakości pracy. „Nie można ogarnąć wszystkiego, zawsze coś po drodze człowiek gubi. Uciążliwe jest notowanie wszystkich zjawisk, analiza dokumentów, ankiet, rozmów" (kobieta, lat 45). Z uzyskanych wypowiedzi można wywnioskować, że nauczyciele pomimo odbytych kursów nie czują się w pełni przygotowani 
do tego, aby na potrzeby ewaluacji wychowania i kształcenia przeprowadzać analizę jakościową wywiadów czy ankiet. Bardzo często nauczyciele wobec natłoku zadań uruchamiają mechanizmy obronne, które polegają na korzystaniu z gotowych opracowań znajdujących się w Internecie. Co gorsza, niektórzy wychowawcy, chcąc „zmieścić się" w granicach przyjętych przez urzędników i chcąc uniknąć konieczności wdrażania systemu naprawczego w sytuacji ujawnienia negatywnych osiągnięć, dopasowują uzyskane wyniki do tych, które są wzorcowe, ustalone przez ministerstwo, jako wyniki oczekiwane. „Nie chcę być nękany przez przełożonych, czy przez kuratorium, dlatego stosuję przekłamania i w ten sposób pozbywam się problemu" (mężczyzna, lat 38).

W kwestii relacji rodzic-szkoła-nauczyciel panuje brak wzajemnego zaufania. Wymaga się od nauczycieli, aby tworzyli nowe protokoły ze spotkań $\mathrm{z}$ rodzicami zawsze tam, gdzie w grę wchodzi negatywne zachowanie ucznia. $Z$ drugiej strony, prosi się także rodziców, aby składali pisemną skargę na nauczyciela, gdy pojawią się okoliczności przemawiające za taką formą reakcji ze strony rodzica. Większość rodziców rezygnuje z takiej formy „dialogu” ze szkołą. Nierzadko jednak rodzice oskarżają nauczycieli, że nie dostosowują wymagań zalecanych przez poradnie rodzinne do poziomu i zachowania oraz wiedzy prezentowanej przez ucznia. Respondenci podzielają jednak zdanie, że tego typu praktyki nie sprzyjają tworzeniu klimatu, który ułatwiałby budowanie wspólnoty wychowawczej.

Ostatnią oznaką biurokratyzacji szkoły jest kwestia obowiązku nauczyciela pracy z uczniem zdolnym i uczniem dysfunkcyjnym, przejawiającym trudności $\mathrm{w}$ zachowaniu i w nauce. Nauczyciele przyznają, że są obciążeni dodatkową pracą (konsultacje z rodzinami, zbieranie zezwoleń, konsultacje z pedagogiem, psychologiem, itp.). W praktyce szkolnej scedowano obowiązki pedagoga i psychologa na wychowawców, a ci uważają, że nie są w pełni kompetentni, aby efektywnie pracować z uczniem trudnym. 


\section{Sztywne, często zmieniające się przepisy, niedopracowane regulaminy, strach przed przełożonym}

Bolączką szkoły są częste zmiany, modyfikacje wprowadzane do regulaminu szkoły. Ustawiczne dopisywanie procedur do regulaminu kreuje chaos w egzekwowaniu postanowień.

Niektórzy respondenci podkreślali, że zbytnie akcentowanie przepisów i niedopracowanie regulaminów oceniania może paraliżować sprawiedliwe egzekwowanie osiągnięć szkolnych ucznia ${ }^{48}$.

Podobna sytuacja występuje w obszarze zachowania ucznia. Do oceny z zachowania brana jest pod uwagę: a) kultura osobista; b) stosunek do obowiązków szkolnych; c) dyscyplina. Ocena z zachowania jest ustalana na podstawie obliczeń średniej arytmetycznej. Nauczyciele zauważają, że może zdarzyć się, iż uczeń mając bardzo negatywny stosunek do obowiązków szkolnych lub do dyscypliny, w końcowym rozrachunku otrzymuje ocenę pozytywną z zachowania, gdyż ustalana jest ona na podstawie obliczeń średniej arytmetycznej.

Nagminne jest zmuszanie nauczycieli przez dyrekcję do podwyższania oceny z zachowania lub zawyżenia oceny $z$ danego przedmiotu. „Ulegamy naciskom ze strony dyrekcji. Być może dyrektor obawia się, że szkoła $z$ tego powodu może utracić dobrą opinię w środowisku" (kobieta, lat 50). Słuchając wypowiedzi można odnieść wrażenie, że respondenci nie są przekonani co do tego typu praktyk, ulegają jednak naciskom, dostosowując się do poleceń przełożonego. W duchu jednak wiedzą, że robią coś negatywnego, co jest przeciwne ich przekonaniom. „Ulegam presji ze strony dyrekcji, robię to dla świętego spokoju. Wiem, że w stosunku do młodszych nauczycieli mogą być wyciągnięte pewne konsekwencje” (mężczyzna, 35 lat). Z dalszych rozmów wynika, że jedną z konsekwencji może być np. brak przedłużenia umowy o pracę.

48 Istnieją przypadki, że uczniowie otrzymują ocenę dostateczną na pierwsze półrocze, na drugie półrocze natomiast ocenę niedostateczną. W tej sytuacji nauczyciel ma obowiązek wystawić ocenę dopuszczającą $(2,0)$. $Z$ tego wynika, że uczeń w drugim półroczu może nie wykazywać żadnego zainteresowania nauką, a na koniec roku szkolnego nauczyciel jest zobowiązany wystawić $\mathrm{mu}$ ocenę pozytywną. Wszystko to dzieje się z uwagi na brak odpowiednich zapisów, które mówiłyby, że uczeń ma obowiązek zaliczyć zarówno pierwsze, jak i drugie półrocze. 
Kuriozalna jest decyzja kuratorium dotycząca obowiązku wpisywania przez nauczycieli zarówno uwag pozytywnych, jak i negatywnych, w sposób bardzo szczegółowy, dokładny, z uwzględnieniem najdrobniejszych scen i wypowiedzi słownych uczniów, nawet tych wulgarnych. Zdaniem respondentów, jest to element pozytywny, nawet jeśli wpisy dokonywane do dziennika pochłaniają wiele czasu, brzmią śmiesznie i zawierają słowa niecenzuralne.

Dużym mankamentem „litery prawa” obowiązującego w szkole jest niemożność wyegzekwowania przez nauczycieli niepisanych reguł dobrego wychowania (np. stosowny strój, schludny wygląd, grzeczny sposób odnoszenia się do drugiego człowieka itp.). Zdaniem respondentów coraz trudniej jest być w szkole „matką" czy „ojcem” dla dzieci, opierając się na wymogach, jakie dyktuje własne serce, sumienie czy też zdrowy rozsądek.

\section{Przejawy ideologizacii przestrzeni szkolnej}

Ideologizacja szkoły, zdaniem respondentów, nie jest fenomenem na wskroś przenikającym wszystkie wymiary życia szkolnego. I tak, nauczyciele zauważają pewne symptomy przerostu ideologii, propagandy nad realnymi możliwościami szkoły. Można to zaobserwować na przykładzie podejścia do zagadnień związanych z Unią Europejską. „Porusza się tematy dotyczące powstania UE, niemalże gloryfikuje się tę unię, tworzy się nowe święta, np. Dzień Unii Europejskiej w szkole, a jednocześnie brak jest w samych podręcznikach krytycznego spojrzenia na problemy związane $\mathrm{z}$ funkcjonowaniem UE, na problemy, które ciągle rodzą się, gdy w grę wchodzi wspólistnienie wszystkich członków UE” (kobieta, lat 51). Respondenci dostrzegają redukowanie wymiaru religijnego wychowania stricte do lekcji religii, przy jednoczesnym zaniedbywaniu takich wydarzeń, jak uczczenie religijnego patrona szkoły. Pewnym symptomem niechęci dyrekcji szkoły do kwestii religii mogą być działania zmierzające do uczczenia patrona szkoły niejako dwutorowo, tzn. poprzez uroczystości obligatoryjne w szkole i uroczystości fakultatywne w kościele. Niemniej zdaniem respondentów szkoła wychodzi naprzeciw potrzebom dzieci, które reprezentują inne wyznania i kultury. Nie dostrzega się oznak zmuszania dzieci do brania udziału w uroczystościach związanych $z$ konkretnym wyznaniem religijnym. Przy omawianiu 
zagadnień, tradycji, zwyczajów związanych z daną religią, jak np. Święta Bożego Narodzenia, dzieci innych wyznań nie biorą udziału w tych zajęciach. Nie zmusza się też dzieci członków zboru Świadków Jehowy do czynności związanych z życiem szkoły (odśpiewanie hymnu państwowego, składanie przyrzeczenia uczniowskiego, itp.).

Wszechobecny wymóg tolerancji zachowań i osób obowiązuje również w szkole. Zdaniem nauczycieli przybiera on jednak formę groteski, gdyż obliguje się szkoły do przyjmowania wszystkich uczniów (niepełnosprawnych intelektualnie i fizycznie, uczniów o odmiennych poglądach religijnych itp.), przy jednoczesnym braku kadry wychowawczo-dydaktycznej, która mogłaby sprostać wymogom pracy $z$ tego typu dziećmi.

Respondenci nie dostrzegają oficjalnych prób wprowadzania ideologii gender do szkoły, ani prób promowania wychowania seksualnego w duchu tejże ideologii. Jednak gdy analizują podręczniki szkolne, dostrzegają, że tematy rodzin rozwiedzionych, rozbitych, gdzie rodzic ma już nowego partnera, są na pozycji uprzywilejowanej $^{49}$. Zdaniem respondentów, podręczniki mają za mało treści pochodzących z literatury pięknej. W czytankach poruszane są zazwyczaj problemy egzystencjalne (narkomania, alkoholizm, patologie w rodzinie i w społeczeństwie) czy wprost uczące, jak ustrzec się przed uzależnieniami, np. "Ja nie biorę", "Ja nie piję". W podręcznikach do szkoły podstawowej jest dużo czytanek, w których brak bohatera, nie ma on imienia, trudno ustalić kolejność zdarzeń. Dostrzegalny jest brak podmiotu lirycznego, bohatera pierwszoplanowego. To dzieci mają same wymyślić, kto jest narratorem. Zdaniem osób badanych, narratorem staje się dziecko, czyli osoba niedojrzała, ucząca się. „Teksty bez wstępu, rozwinięcia, bez wyodrębnienia poszczególnych wydarzeń, bez imion bohaterów, nie posiadające logicznej całości, prowokują odbiorcę do dowolnej interpretacji, co nie jest wskazane na tym etapie kształcenia” (kobieta, lat 44).

Ważnym stwierdzeniem respondentów jest to, iż w podręcznikach do klas 1-3 nie zauważono treści sprzecznych ze zdobyczami nauki. Tak więc nie zauważa się, aby lansowano ideę wychowania czy adopcji dzieci przez dwóch mężczyzn/dwie kobiety. Pewne oznaki

49 Zob. H. Januszewska, Ja i mój świat, Nauczanie I-III, cz. VIII, czytanka Basia, Kielce 2011, s. 68. 
ideologizacji uczniów można jednakże zauważyć w podręcznikach, które podkreślają Dzień Zmarłych, pomijając przy tym rangę uroczystości Wszystkich Świętych.

Respondenci przyznają, że szkolenia nauczycieli w ramach WDN mają różnorodną tematykę np. a) jak radzić sobie z uczniem dysfunkcyjnym; b) z uczniem mało zdyscyplinowanym i z tym, który ujawnia ADHD; c) aktywizowanie uczniów na lekcji; d) stosowanie nowoczesnych metod nauczania; e) wykorzystywanie multimediów $\mathrm{w}$ nauczaniu. Wspomniane szkolenia obowiązkowe, prowadzone z ramienia kuratorium, nie mają jednak charakteru ideologizowania nauczycieli, ani też nie promują żadnej ideologii.

\section{Wnioski i postulaty}

1. Celem uniknięcia stosowania przekłamań i uzyskiwania nierzetelnych wyników ewaluacji szkoły, respondenci proponują, aby szkoła sama wypracowywała kryteria oceny pracy na bazie własnych doświadczeń, porażek i możliwości intelektualnych oraz wychowawczych swoich uczniów.

2. Respondenci pozytywnie oceniają możliwość dokonywania szczegółowych opisów zachowania ucznia, uwzględniając w dzienniku jego słowa wypowiedziane względem nauczycieli (nawet jeśli niecenzuralne), wyrażone gesty, itp. Zdaniem osób badanych, owe wpisy mogą posłużyć jako materiał dowodowy przeciwko uczniom, którym grozi przydzielenie kuratora sądowego. Paradoksalnie, wspomniana biurokratyzacja może przynieść również pozytywne efekty. Owe „materiały” pomagają nauczycielom i dyrekcji we wszczynaniu postępowania dyscyplinarnego względem uczniów, którzy notorycznie łamią regulamin szkoły, a rozmowy z ich rodzicami nie przynoszą oczekiwanych efektów. Inną stroną pozytywną tak szczegółowego odnotowywania uwag jest to, że tego typu wpisy stają się materiałem dowodowym do wykorzystania przeciwko rodzicom roszczeniowym, którzy notorycznie kontestują i podważają czynności podjęte przez nauczycieli przeciwko dziecku.

3. Osoby badane zauważają, że regulamin szkoły czy inne zapisy prawne nie zawierają szczegółowego wykazu prawidłowych form zachowania przewidzianych na każdą okoliczność. W sytuacjach spornych, gdy w grę wchodzi wyegzekwowanie niepisanych reguł dobrego 
wychowania, trudno wychowywać bez odniesienia do zdrowego rozsądku i do podpowiedzi płynących z serca. Praktyczne przeakcentowanie zapisów prawnych oraz rozwiązań biurokratycznych kosztem zdrowego rozsądku i zasad niepisanych dobrego wychowania może potęgować w nauczycielach postawę wycofania i rezygnacji z wychowania do tego wszystkiego, co zwie się sferą ogólnoludzką.

4. Akcentowanie roli UE w życiu społeczeństwa, podkreślanie tzw. wartości europejskich prowadzi do apoteozy UE, kosztem innych wartości i realiów życia, które w życiu młodego człowieka są notorycznie zaniedbywane lub uszczuplane.

5. Obserwuje się duży napór na szkołę, aby funkcjonowała według wymogów tolerancji i równości, bez jednoczesnego zweryfikowania, czy jest ona w stanie wyjść naprzeciw problemom rodzącym się w kontekście szkoły, np. powodowanym przez niepełnosprawne dzieci czy też dzieci pochodzące z innych kultur. Wspomniany napór ma zabarwienie ideologiczne, bowiem nie bierze pod uwagę realnych możliwości szkoły, a jedynie ślepe posłuszeństwo propagandzie i idei tolerancji jako wartości nadrzędnej.

6. Pozytywnym jest fakt, że treści zawarte w podręcznikach poruszają realne problemy dzieci np. brak akceptacji niepełnosprawnych, brak tolerancji w stosunku do ludzi o odmiennej kulturze. Sporną pozostaje jednak kwestia braku narratora w ukazywanych czytankach, co rodzi swego rodzaju dowolność interpretacji i pozbawia osobę dorosłą (wychowawcę) wpływu na dziecko za pomocą przekazywanych treści i możliwości ukazywania życiowych wzorców (bohaterów).

7. Respondenci nie dostrzegają jawnych sprzeczności pomiędzy osiągnięciami nauk a treściami lansowanymi zawartymi w podręcznikach. W kwestii rodziny szanuje się ideę, że dziecko rozwija się prawidłowo - duchowo, psychicznie, intelektualnie, gdy obecne są obydwa rodzicielskie komponenty: męski i żeński.

8. Ważne miejsce w życiu szkoły z punktu widzenia wielokulturowości zajmują działania i zwyczaje, które są dowodem na to, że placówka jest wyczulona na sprawy uczniów innych wyznań i kultur. Pozostaje jednak sporna kwestia, na ile owe czynności lub ich brak sprzyjają tworzeniu klimatu tolerancji i wzajemnego ubogacania się między wychowankami, którzy reprezentują odmienne kody kulturowe. Dyskusyjna, zdaniem autora, jest rezygnacja szkoły ze stwarzania dzieciom sprzyjających warunków do wzajemnego ubogacania się za 
pomocą wspólnej zabawy, poznawania zwyczajów i obrzędów innych religii czy kultur. Tolerancji bowiem nie można uczyć się na zasadzie wyeliminowania z życia szkolnego wszystkich kwestii spornych, działań, zwyczajów, ale właśnie wypełniając tę przestrzeń „innością”, by dać okazję do jej poznania, dostrzeżenia pewnych wspólnych wartości łączących wiele wyznań i kultur.

\section{Bibliografia}

Abp Hoser, Gender to wielkie ktamstwo, w: http://wiadomosci.wp.pl/ kat,137914,title,Abp-Hoser-gender-to-wielkie-klamstwo,wid,1628955 8,wiadomosc.html?ticaid=115ead [dostęp: 10.11.2015].

Absurdy biurokratyczne w oświacie, w: http://www.warszawskieforumoswiatowe.pl/index.php?site=hsite\&id=17 [dostęp: 04.11.2015]

Amato G., Gender (d)Istruzione. Le nuove forme d'indottrinamento nelle scuole italiane, Fede \& Cultura, Verona 2015.

Autor anonimowy, Biurokracja zabija szkote, w: http://wyborcza.pl/ma gazyn/1,128598,12659823,Biurokracja_zabija_szkole.html?disable Redirects=true [dostęp: 04.11.2015].

Banach Cz., Polska szkota $i$ system edukacji - przemiany i perspektywy, Wydawnictwo Adam Marszałek, Torun 1999.

Dąbrowska-Bąk M., Pawełek K., Opresja w szkole, Wydawnictwo Akademickie „Żak”, Warszawa 2014.

De Beauvoir S., Druga płé,, przeł. G. Mycielska, Wydawnictwo Literackie, Kraków 1972.

Frezza E., Mala Scuola - "Gender", affettività, emozioni: il sistema "educativo" per abolire la ragione e manipolare i nostri figli, Casa Editrice Leonardo da Vinci, Roma 2017.

Galant J., Czy szkota może być neutralna światopoglądowo?, „Nowa Szkoła” 1997, nr 5, s. 11-14.

Giddens A., Socjologia, przeł. O. Siara i inni, Wydawnictwo Naukowe PWN, Warszawa 2012.

Górecki A., Edukacja (deprawacja) seksualna przejawem ideologizacji szkoty, w: http://christianitas.org/news/edukacja-deprawacja-seksualna-przejawem-ideologizacji-szkoly/ [dostęp: 08.11.2015].

Grabek A., Szkota przesiąnięta biurokracja, w: http://praca.gazetaprawna. pl/artykuly/550588,szkola_przesiaknieta_biurokracja.html [dostęp: 04.11.2015].

Jackowski J.M., Szkota nadal w okowach ideologii, w: http://www.radiomaryja.pl/bez-kategorii/szkola-nadal-w-okowach-ideologii/ [dostęp: 10.11.2015]. 
Jaroszyński P., Cztowiek i nauka, Polskie Towarzystwo Tomasza z Akwinu, Lublin 2008.

Joanna-Kluzik-Rostkowska: szkota publiczna powinna być neutralna światopogladowo, w: http://wiadomosci.wp.pl/kat,1342,title,Joanna-Kluzik-Rostkowska-szkola-publiczna-powinna-byc-neutralna-swiatopoglado wo,wid,16784101,wiadomosc.html?ticaid=115ee0 [dostęp: 12.11.2015].

Kącki A., Niemoc wychowania w szkole jako nastęstwo braku koncepcji wychowania, czyli o autarkii $i$ acedii postmodernistycznej pedagogiki, w: Wychowanie w szkole: od bezradności ku możliwościom, red. R. Chałupniak, T. Michalewski, E. Smak, Wydział Teologiczny Uniwersytetu Opolskiego, Opole 2014, s. 81-86.

Kłakówna Z.A., Opinia na temat listy lektur zjezyka polskiego w szkole podstawowej z widokiem na gimnazjum i liceum. Klasy I-III (I etap edukacyjny) oraz klasy IV-VI (drugi etap edukacyjny), „Horyzonty Polonistyki” 2008, nr 1, s. 8-11.

Kowalski M., Nobilitowanie ideologii spotecznych przy pomocy nauki (ideologizowanie nauki) - analizy i refleksje, „Rocznik Lubuski” 2012, t. 38, cz. 2, s. 191-199.

Krukowski J., Kościót i państwo, podstawy relacji prawnych, Redakcja Wydawnictw KUL, Lublin 2000.

Kuby G., Rewolucja genderowa. Nowa ideologia seksualności, Wydawnictwo Homo Dei, Kraków 2007.

Magdziak Z., Mniej biurokracji w szkole, w: http://www4.rp.pl/artykul/ 945624-Mniej-biurokracji-w-szkole.html [dostęp: 04.11.2015].

Milerski B., Edukacja religijna w szkole neutralnej światopogladowo, w: http:// ekumenia.pl/wp-content/uploads/2014/03/Edukacja-religijna-w-szkole-neutralnej-swiatopogladowo-B.Milerski.pdf [dostęp: 12.11.2015].

Mucci G., I cattolici nelle temperie del relativismo, Jaca Book, Milano 2005.

Nowak B., w wywiadzie dla P. Ogórek, PIS: zdemolowano caty system nauczania, w: http://wiadomosci.onet.pl/krakow/pis-zdemolowano-caly-system-nauczania/p4dhnf [dostęp: 04.11.2015].

Nowak M., Edukacja daleka od chrześijaństwa, w: http://www.fronda.pl/a/ edukacja-daleka-od-chrzescijanstwa,31291.html [dostęp: 10.11.2015].

Nowak M., Filozofia cztowieka podstawa filozofii wychowania, w: Wychowanie personalistyczne, Wybór tekstów, red. F. Adamski, Wydawnictwo WAM, Kraków 2005, s. 133-154.

Nowak M., Koncepcja szkoty i jej zadania we wspótczesnej myśli pedagogicznej, w: Szkota-Nauczyciel - Uczeń, red. T. Kukołowicz, Wydział Nauk Spolecznych KUL, Stalowa Wola 1992, s. 9-22.

Oakley A., Sex, Gender and Society, Published by Maurice Temple Smith, Londyn 1972.

Pabis M., Neutralna, czyli ateistyczna, w: http://www.naszdziennik.pl/polska-kraj/88411,neutralna-czyli-ateistyczna.html [dostęp: 12.11.2015]. 
Pająk J., Kultura organizacyjna w oświacie. Teoria - praktyka - stymulacja, Sląsk Sp. z o.o., Wydawnictwo Naukowe, Katowice 1996.

Posacki A., Szkoła tatwych pocieszeń czy dogmatyzacja fatszywych dylematów?? w: http://www.radiomaryja.pl/bez-kategorii/szkola-latwych-pocieszen-czy-dogmatyzacja-falszywych-dylematow/ [dostęp: 10.11.2015].

Possenti V., L'uomo postmoderno, Marietti, Milano 2009.

Rykiel Z., Szaleństwo czy metoda? Modernizacja przez biurokratyzacje i prekaryzacje, w: http://socialspacejournal.eu/8\%20numer/Zbigniew\%20 Rykiel\%20-\%20Szale\%C5\%84stwo\%20czy\%20metoda.pdf [dostęp: 04.11.2015].

Sawiński J.P., Jak ujarzmić (eliminować) szkolna biurokrację?, w: http://www. edunews.pl/badania-i-debaty/opinie/1745-jak-ujarzmic-eliminowac-szkolna-biurokracje [dostęp: 4.11.2015].

Stańkowski B., Meanders of upbringing and worldview neutrality, w: Rolul Europei într-o societate polarizată. Conferinţa internațională de drept, studii europene şi relaţii internaţionale, Universitatea Titu Maiorescu, Bucureşti, 9-10 mai 2014, s. 830-845.

Śliwerski B., Nauki o wychowaniu wobec wyzwań postmodernizmu, „Chowanna"2003, t. 1 (20), s. 9-18.

Śliwerski B., Na horyzoncie wyborów do Sejmu-MEN-owska polityka btędów: arogancji, ignorancji, centralizmu i biurokratyzacji, w: http://sliwerski-pedagog.blogspot.com/2015/07/na-horyzoncie-wyborow-do-sejmu-men-ska.html [dostęp: 12.03.2019].

Śliwerski B., Pozory sprawstwa reform oświatowych w III RP, w: Sprawcy i/ lub ofiary dziatań pozornych w edukacji szkolnej, red. M. Dudzikowa, K. Knasiecka-Falbierska, Oficyna Wydawnicza „Impuls”, Kraków 2013, s. $103-130$.

Ślusarczyk M. Spory o edukacje wczoraj i dzis, Krakowskie Towarzystwo Edukacyjne - Oficyna Wydawnicza AFM, Kraków 2010.

Warecki K., Nauczyciel jako funkcjonariusz ideologii, w: http://gosc.pl/ doc/2197730.Nauczyciel-jako-funkcjonariusz-ideologii/2 [dostęp: 10.11.2015].

Wielomski A., Genderyzm czyli szaleństwo importowane z zachodniego śmietnika ideologii, w: http://nczas.com/publicystyka/genderyzm-czyli-szalenstwo-importowane-z-zachodniego-smietnika-ideologii/ [dostęp: 10.11.2015].

Wilgocki M., Arcybiskup Gq̨decki do minister edukacji: Neutralnośc swiatopogladowa? Niemożliwa do spetnienia, w: http://wyborcza.p1/1,76842, 16409224,Arcybiskup_Gadecki_do_minister_edukacji_Neutralnosc. html?disableRedirects=true [dostęp: 12.11.2015].

Zagtada tożsamości w ideologii gender, w: https://prawdaxlxpl.wordpress. com/2013/04/21/ [dostęp: 09.11.2015].

Zalewski D., Absurdy liberalnej szkoty, w: http://cywilizacja.ien.pl/?id=504 [dostęp: 12.11.2015]. 
Zalewski D., Antypedagogika i inne herezje, w: http://www.psychologia.net. pl/e-booki/Dariusz_Zalewski-Antypedagogika_i_inne_herezje.pdf [dostęp: 12.11.2015].

Zellma A., Wspótczesny katecheta - między chrześcijanskim powotaniem i misja a idea gender, w: A. Jucewicz, M. Machinek, Idea gender jako wyzwanie dla teologii, Wydawnictwo „Hosianum”, Olsztyn 2009, s. 173-185.

\section{ADRES DO KORESPONDENCJ}

Ks. dr hab. Bogdan Stańkowski, prof. AlK

Akademia Ignatianum w Krakowie

Wydział Pedagogiczny

Instytut Nauk o Wychowaniu

e mail: bogdan.stankowski@ignatianum.edu.pl 